Article

\title{
Fire Spread of Thermal Insulation Materials in the Ceiling of Piloti-Type Structure: Comparison of Numerical Simulation and Experimental Fire Tests Using Small- and Real-Scale Models
}

\author{
Heong-Won Suh ${ }^{1}$, Su-Min Im ${ }^{1}$, Tae-Hoon Park ${ }^{1}$, Hyung-Jun Kim ${ }^{2}$, Hong-Sik Kim ${ }^{3}$, \\ Hyun-Ki Choi ${ }^{4}$, Joo-Hong Chung ${ }^{5}$ and Sung-Chul Bae ${ }^{1, *(\text { D }}$ \\ 1 Department of Architectural Engineering, Hanyang University, Seoul 04763, Korea; \\ christ1205@hanyang.ac.kr (H.-W.S.); isumin@hanyang.ac.kr (S.-M.I.); evanpark@hanyang.ac.kr (T.-H.P.) \\ 2 Hazard Mitigation Evaluation Technology Center, Korea Conformity Laboratories, Cheongju 28115, Korea; \\ arc7707@kcl.re.kr \\ 3 National Fire Science Research Center, Ministry of Public Safety and Security, Chungnam 31555, Korea; \\ yurimgas@korea.kr \\ 4 Department of Fire and Disaster Prevention Engineering, Kyungnam University, Changwon 51767, Korea; \\ chk7796@kyungnam.ac.kr \\ 5 Department of Architecture, Sahmyook University, Seoul 01795, Korea; scarletmoon@syu.ac.kr \\ * Correspondence: sbae@hanyang.ac.kr; Tel.: +82-2-2220-0302
}

Received: 30 May 2019; Accepted: 15 June 2019; Published: 19 June 2019

check for updates

\begin{abstract}
Large-scale fires mainly due to the ignition of thermal insulation materials in the ceiling of piloti-type structures are becoming frequent. However, the fire spread in these cases is not well understood. Herein we performed small-scale and real-scale model tests, and numerical simulations using a fire dynamics simulator (FDS). The experimental and FDS results were compared to elucidate fire spread and effects of thermal insulation materials on it. Comparison of real-scale fire test and FDS results revealed that extruded polystyrene (XPS) thermal insulation material generated additional ignition sources above the ceiling materials upon melting and propagated and sustained the fire. Deformation of these materials during fire test generated gaps, and combustible gases leaked out to cause fire spread. When the ceiling materials collapsed, air flew in through the gaps, leading to flashover that rapidly increased fire intensity and degree of spread. Although the variations of temperatures in real-scale fire test and FDS analysis were approximately similar, melting of XPS and generation of ignition sources could not be reproduced using FDS. Thus, artificial settings that increase the size and intensity of ignition sources at the appropriate moment in FDS were needed to achieve results comparable to those recorded by heat detectors in real-scale fire tests.
\end{abstract}

Keywords: fire spread; fire dynamic simulator; real-scale test; thermal insulation

\section{Introduction}

The importance of energy saving in buildings is growing worldwide, and the standards for insulation of the building envelope have been reinforced. Consequently, ceiling and thermal insulation materials are applied to reduce heat flows by conduction, convection, and radiation in building structures. However, these materials are mostly organic in nature, which are easily ignited and generate large volumes of toxic gases like $\mathrm{CO}$ and $\mathrm{CO}_{2}$ during combustion, thus increasing the casualties in the event of a building fire [1-4]. Furthermore, even though there are legal standards about the flame-retardant performance of thermal insulation materials, there is insufficient research on the correlation between the flame-retardant performance of thermal insulation materials and the 
fire hazards of buildings. Thus, materials with low flame-retardant performance have been used in buildings, causing many incidents of fire spread [1-4].

Piloti structures are used as supports to lift a building above ground or water. In South Korea, piloti structures are often used in urban buildings to solve the car parking difficulties of multi-household and multi-family houses (Figure 1). Since piloti structures are increasingly being used for parking spaces, the risk of large-scale fires has increased owing to the combination of fire spread risks, including high wind pressure and continuous oxygen supply, with poor evacuation zoning due to the nature of the piloti structure $[5,6]$. In fact, the thermal insulation materials of piloti structures were found to be the cause of fire spread in different large-scale fires that have occurred in South Korea $[7,8]$. In most cases, the fire spread process in piloti structures with thermal insulation materials can be described as follows [5]. First, the thermal insulation materials inside the ceiling are burned by the fire caused by unorganized electric wires (as a result of entanglements, sheath removal, gnawing by mice, etc.) inside the ceiling on the first floor of the piloti structure. Then, the burned thermal insulation materials collapse to the bottom ceiling materials under gravity and burn them $[7,8]$. Furthermore, there is the continuous supply of oxygen generated by a wind pressure higher than that in the surrounding areas, which is a characteristic of piloti structures. This leads to large-scale fires [7-9].

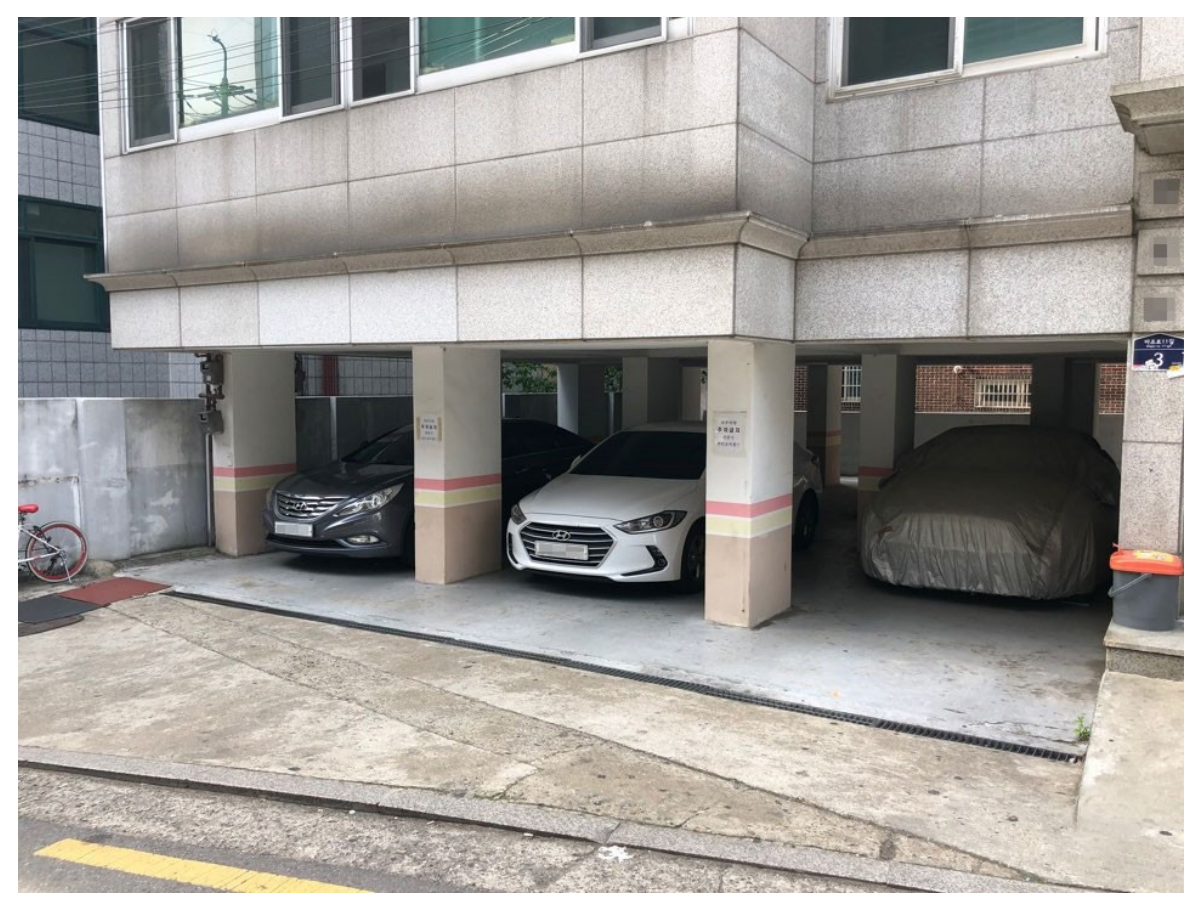

Figure 1. Piloti structures used to make parking space in Korea.

However, the spread in the ceiling of piloti structure has not been elucidated because the only reliable way to accurately estimate the flame behavior was by camera recordings at the time of the fire and from the soot of buildings after the fire, making it difficult to find the exact cause [8]. Therefore, a study based on the reproduction of the situation in the same structure as that of the building in which the fire occurred is required to reveal the flame behaviors at the time of the fire more accurately. The data collection methods in this research include a real-scale fire test [10-17], in which the main part or the whole structure where the fire occurred is constructed and a fire is intentionally generated [10-16], and a fire simulation, in which data are collected by computer simulation of the structure [18-25].

The real-scale fire test, which reproduces the building structure considered vulnerable to fire and actually generates a fire, is costly and time-consuming because the building must be reproduced using actual building materials. Thus, given that the experiment cannot be performed multiple times, it is difficult to determine its accuracy and limitations only from the results of one experiment $[14,19]$. 
Furthermore, it is impossible to perfectly reproduce the actual fire site and it is unclear whether the experimental results are directly related to the actual fire situation because many complex factors are involved, such as the characteristics of materials exposed to fire and the supply of oxygen. Therefore, previous studies have improved the accuracy of the results of a real-scale fire test by comparing them with the results of a numerical fire simulation that uses the same material properties and firepower of the real-scale test $[14,19]$.

Fire simulation is a computer programming technique used to predict and analyze possible damage based on flame spread behavior, smoke spread shape, visible distance, temperature, $\mathrm{CO}$ concentration, and $\mathrm{CO}_{2}$ concentration in the event of a fire in a virtual space of a house or building. The fire dynamics simulator (FDS) is the most widely used simulation tool to analyze the flame and smoke behavior in the event of a large-scale fire for performance-based fire protection design $[18-21,25,26]$ because it can reproduce actual building shapes and structures larger than those that can be implemented in real-scale fire tests. However, owing to the nature of the FDS, which is based on hydrodynamic and thermodynamic analyses, it has limited accuracy. Using FDS, it is difficult to analyze the changes in material properties, such as material removal, melting, and deformation, that can occur when there is a fire in a building. Thus, predicting parameters like inflow of oxygen is very challenging $[19,20,26]$. To improve these shortcomings, the limitations of the simulation must be researched via a comparison between it and the real-scale fire test, and the changes in material properties at the time of the fire must be assessed $[27,28]$.

Herein we analyze the flame behavior upon ignition of thermal insulation materials in the ceilings of a piloti structure by comparing the results of small-scale and real-scale model tests with those obtained with the FDS. First, the temperature changes according to the degree of fire spread and the temporal changes are examined for the thermal insulation materials of the ceiling via a preliminary ignition test that identifies the properties of the thermal insulation materials upon ignition and a small-scale model test that simulates the space inside the ceiling. Based on the results of these tests, the moving path of the heat inside the ceiling and the cause of the spread to large-scale fires are investigated in a real-scale piloti structure. In addition, the material properties, such as the heat release rate of thermal insulation and ceiling materials, are obtained via a cone calorimetry test and are applied to the FDS. They are compared with those of the real-scale fire tests through an analysis of the heat diffusion and smoke behaviors. Then, the limitations of each test method and the corresponding improvement measures are outlined, and the flame behavior upon ignition of thermal insulation materials in piloti-type ceilings is analyzed.

\section{Materials and Methods}

\subsection{Test Materials}

As the thermal insulation materials in this test, extruded polystyrene (XPS), which is applied in most building structures owing to its excellent constructability and economic efficiency, and flame-retardant expanded polystyrene foam (EPSFs), which is a representative material with semi-incombustible performance [29,30], were used. XPS is produced through extrusion molding by adding a hydrocarbon foaming agent to a polystyrene resin [1,2,31-33]. It has been used in buildings in South Korea where large-scale fires have occurred, and the cause of the fire spread was found to be the thermal insulation materials [2,31,32]. EPSFs are semi-incombustible thermal insulation materials produced by preliminary foaming of raw material beads produced using polystyrene resin and a hydrocarbon foaming agent, filling them in a mold, and foaming it 30-80 times depending on the heating [29,30].

Furthermore, two ceiling materials are recognized as another cause for fire spread $[7,8]$ in piloti-structure buildings: Sheet molding compound (SMC) and design metal ceiling (DMC). The SMC ceiling material, which is a thermosetting resin, has the advantage of resistance to humidity and pollution [34]. The DMC is a semi-combustible and environment-friendly ceiling material but may be inappropriate for places with humidity because it contains metals [35]. 
Each situation for using each material are abbreviated. For example, when XPS is used as thermal insulation and SMC is used as ceiling materials, the structures are named as 'XPS + SMC'.

\subsection{Cone Calorimetry Test}

The cone calorimetry test was conducted to measure the characteristics of the materials used in the test in accordance with the KS F ISO 5660-1 standard. Specimens with dimensions of $100 \mathrm{~mm}$ $\times 100 \mathrm{~mm}$ and heights of $50 \mathrm{~mm}$ or less were prepared (Figure 2). The radiation heat and emission flow of the cone heater are set and maintained at $50 \mathrm{~kW} / \mathrm{m}^{2}$ and $0.024 \mathrm{~m}^{3} / \mathrm{s}$, respectively. After the radiation heat blocking device is removed, the specimen is heated for $5 \mathrm{~min}$. The tests were conducted under the following conditions. The total emitted calorific value for $5 \mathrm{~min}$ after starting the heating test must be less than $8 \mathrm{MJ} / \mathrm{m}^{2}$ and the maximum heat release rate for 5 min must not exceed $200 \mathrm{~kW} / \mathrm{m}^{2}$ continuously for more than $10 \mathrm{~s}$. Furthermore, there must be no harmful cracks, holes, and melting that penetrate through the specimens after heating for $5 \mathrm{~min}$. The tests were conducted three times with the heating intensity of $50 \mathrm{~kW} / \mathrm{m}^{2}$. The thicknesses of the XPS, EPSFs, DMC, and SMC specimens were $50,50,0.4$, and $1.5 \mathrm{~mm}$, respectively.

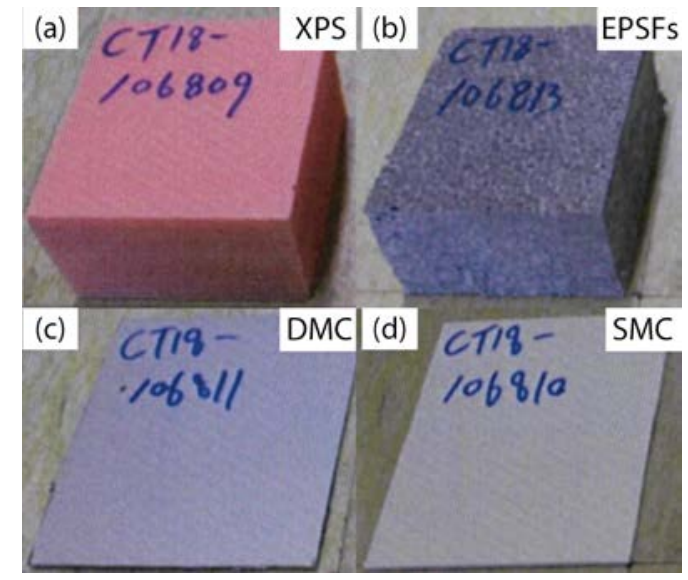

Figure 2. Appearances of materials used in the cone calorimetry test: (a) Extruded polystyrene (XPS), (b) expanded polystyrene foams (EPSFs), (c) design metal ceiling (DMC), and (d) sheet molding compound (SMC).

\subsection{Preliminary Ignition Test}

The preliminary ignition test was performed to examine the temporal changes in the thermal insulation and ceiling materials and the problems associated with each of them according to the fire duration. In this study, the internal structure of the ceiling space in which the worst fire situation (XPS $+\mathrm{SMC}$ ) was simulated in the main test was assumed for the preliminary ignition test. The XPS at the top was burnt by direct contact with the fire source to examine the changes in its properties when exposed to fire, and the changes that happened when the molten XPS was deposited on the SMC were observed. The thermal insulation and ceiling materials were separated by $\sim 50 \mathrm{~cm}$ in this test.

\subsection{Small-Scale Model Test}

Before a real-scale fire test, a small-scale fire test was performed to examine the fire resistance and flame behavior of each material. The specimens were scaled down with the same structure as that of the materials installed at the site, to obtain a unit modular structure $(1 \mathrm{~m} \times 0.8 \mathrm{~m})$ (Figure 3$)$. The small-scale fire test was performed with three experimental groups, as shown in Figure 3: (i) XPS + SMC structure, which has been applied to the ceilings of many piloti-type buildings in South Korea, (ii) EPSFs + SMC structure, in which thermal insulation materials with semi-incombustible performance are installed, 
and (iii) XPS + DMC structure, in which heat-resistant ceiling materials are installed. Circular ignition sources of diameter $10 \mathrm{~cm}$ were used, and kerosene was used as fuel.
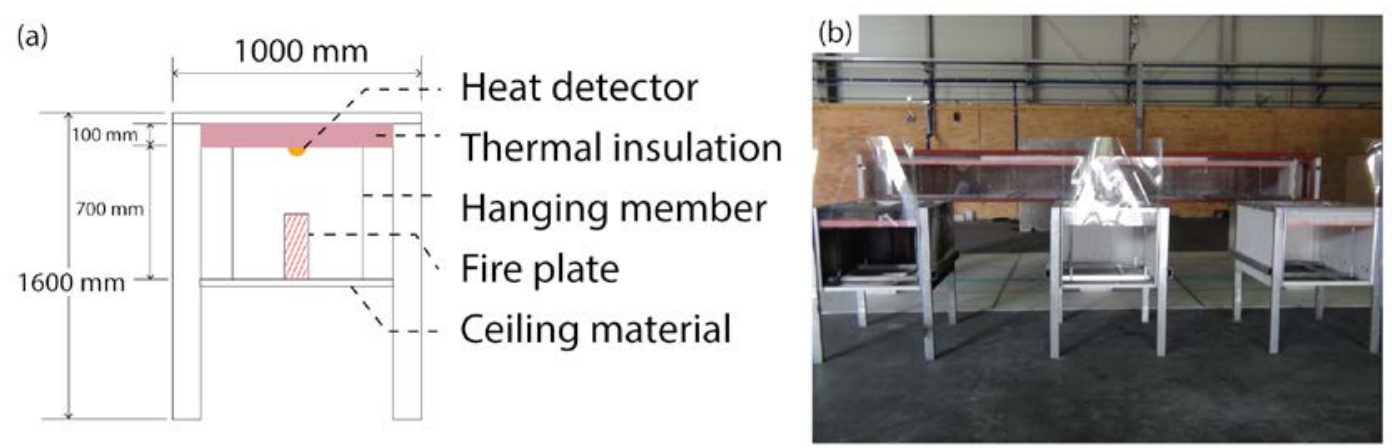

Figure 3. (a) Design of a small-scale model, (b) specimens for the small-scale test (left: XPS + SMC, middle: EPSFs + SMC, right: XPS + DMC).

\subsection{Real-Scale Fire Test}

For this test, the specimens were fabricated with the same structure as those found inside the ceiling of the first floor of an actual piloti-type building (Figure 4). As the ignition source, kerosene with a heat release rate of $1680.0 \mathrm{~kW} / \mathrm{m}^{2}$ was used, and the dimension of the ignition source was $400 \mathrm{~mm} \times$ $200 \mathrm{~mm} \times 100 \mathrm{~mm}$. Heat detectors were installed at 14 places at intervals of $\sim 90 \mathrm{~cm}$, where the thermal insulation materials contact the top concrete structure. The test was performed twice. Real-scale fire tests of EPSFs + DMC, which is the best case, and XPS + SMC, which is the worst case, were conducted by assuming a fire accident, with the maximum closed state of the specimens. Considering a peak fire situation, the smoke generated during the test was discharged using a 10-MW-class dust collector. The spacing between the columns which were made of fireproof blocks was $3 \mathrm{~m}$, corresponding to the spacing in a parking lot. To examine the test situation, polycarbonate was applied to one side of the specimens to facilitate thermographic measurement and video recording. Data with no outliers in the thermogram were excluded from the analysis. The analysis focused on heat detectors, HD1, HD2, and HD3. Seven heat detectors for temperature measurement were installed at the top of the thermal insulation materials and at the bottom of the ceiling materials at fixed intervals. The positions of the heat detectors are illustrated in Figure 4. The specimens were sealed to the maximum, but when the firepower decreased due to insufficient oxygen, the polycarbonate wall on the left (W1) of the elevation was removed to reflect the characteristic of a piloti structure, in which air can freely flow.

\subsection{Fire Dynamics Simulation (FDS)}

The FDS was performed by fabricating a structure identical to the drawing of the real-scale model test, using kerosene as the fuel and an ignition source with the same size as that of the real-scale model fire test. For the properties of the materials, the measurements obtained using the cone calorimetry tests were applied. The simulation was performed using the application Pyrosim 2018, which uses FDS 6.6.0. [36-39]. The grid and cell size applied to the FDS are outlined in Table 1. 


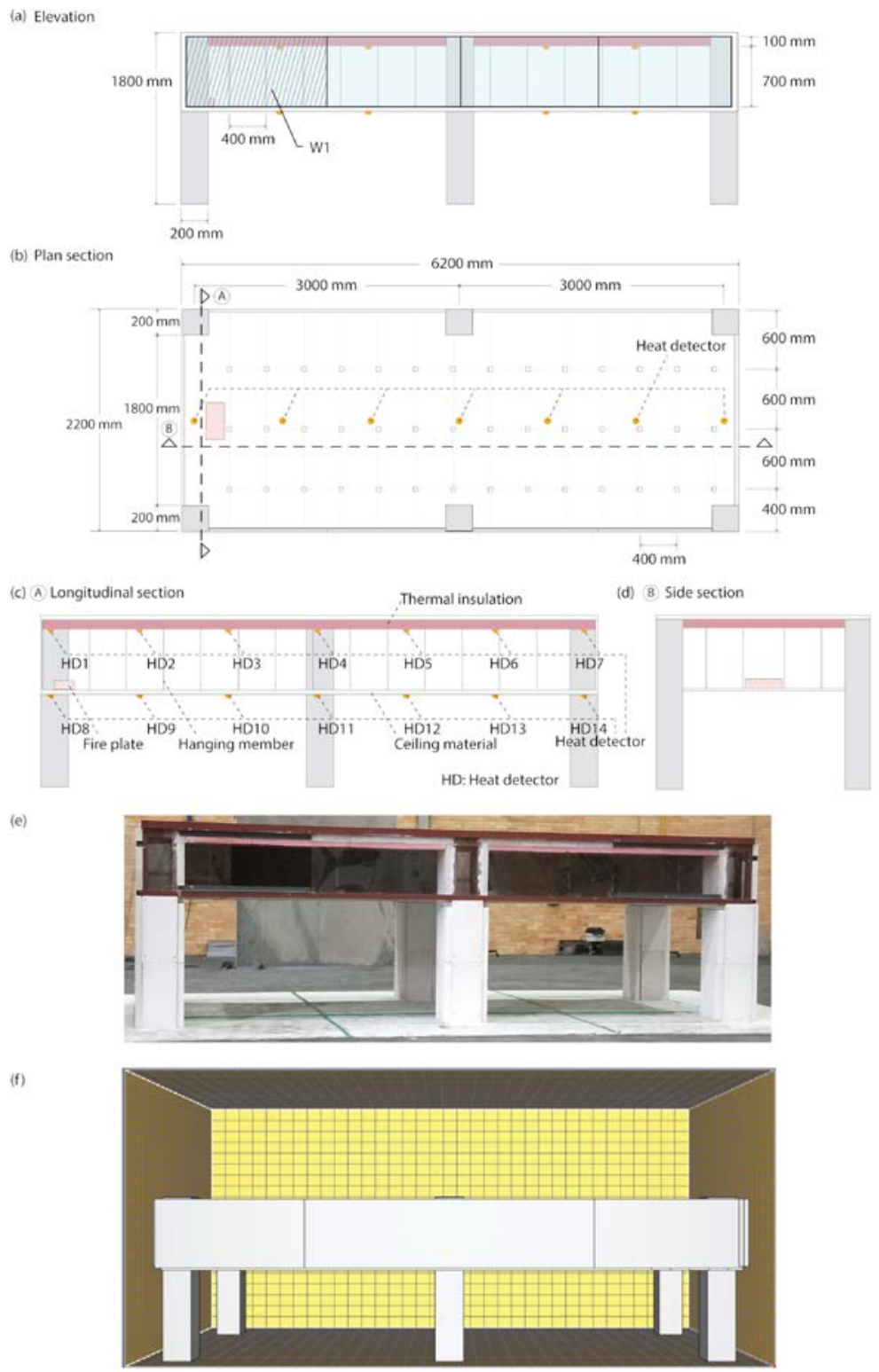

Figure 4. Schematics of the real-scale fire test model (a) elevation, (b) plan section, (c) longitudinal section, (d) side section, and (e) representation of real-scale fire test model, and (f) schematics of fire dynamics simulator (FDS) model. The positions of the real-scale model heat detectors are indicated as HD1-HD14 in (c). HD: Heat detector.

Table 1. Mesh boundary, cell number, cell size ratio, and cell size in axial direction.

\begin{tabular}{ccccc}
\hline & Mesh Boundary & Cell Number & Cell Size Ratio & Cell Size (m) \\
\hline X & $-0.3-2.8 \mathrm{~m}$ & 21 & 1.02 & 0.1527 \\
$\mathrm{Y}$ & $-0.2-6.3 \mathrm{~m}$ & 35 & 1.25 & 0.1875 \\
$\mathrm{Z}$ & $0.0-3.0 \mathrm{~m}$ & 20 & 1.00 & 0.1500 \\
\hline
\end{tabular}

The schematics of the FDS model are shown in Figure 4f. The dimension of the FDS model was identical to the real-scale model (Figure $4 \mathrm{a}$ ). The size of the mesh boundary was $3.1 \mathrm{~m} \times 6.5 \mathrm{~m} \times$ $3.0 \mathrm{~m}$ and the cell size in the grid was $0.1527 \mathrm{~m} \times 0.1875 \mathrm{~m} \times 0.1500 \mathrm{~m}$ (total grid number: 17,700). The environment temperature and humidity were set to $20^{\circ} \mathrm{C}$ and $40 \%$, respectively. In addition, the specific heat of Kerosene (heat source) as set to $2.6 \mathrm{~kJ} /(\mathrm{kg} \cdot \mathrm{K})$. To apply same fire load with real-scale fire, heat release of fire was changed from $0 \%$ to $100 \%$ when 50 seconds passed after ignition. 


\section{Results and Discussion}

\subsection{Cone Calorimetry Test}

Table 2 and Figure 5 depict the results of cone calorimetry test of each specimen and comparison between each specimen in terms of heat release rate and mass variation, respectively. According to the test results, the total heat release of XPS was higher than that of EPSFs by $7.4 \mathrm{MJ} / \mathrm{m}^{2}$. In contrast to SMC, which released $22 \mathrm{MJ} / \mathrm{m}^{2}$ of heat, DMC only released a small amount of heat, $0.4 \mathrm{MJ} / \mathrm{m}^{2}$. Furthermore, the peak heat release rate of XPS was higher than that of EPSFs. SMC showed a high peak heat release rate, $350.11 \mathrm{MJ} / \mathrm{m}^{2}$, whereas DMC only released a small amount of heat, $1.72 \mathrm{MJ} / \mathrm{m}^{2}$. XPS, EPSFs, and SMC consumed similar amounts of total oxygen (10-15 g) whereas DMC consumed only a small amount of oxygen (0.17 g). XPS and EPSFs showed small mass losses of 12.4 and $8.13 \mathrm{~g} / \mathrm{m}^{2}$, respectively, while SMC and DMC showed large mass losses of 1074.63 and $66.40 \mathrm{~g} / \mathrm{m}^{2}$, respectively. These differences in the mass loss were caused by the different densities of the materials. XPS, EPSFs, and SMC produced similar volumes of smoke, whereas DMC produced a relatively small volume of smoke.

Table 2. Cone calorimeter test results (between 0 and $600 \mathrm{~s}$ ).

\begin{tabular}{ccccc}
\hline & XPS & EPSFs & SMC & DMC \\
\hline Total heat release $\left(\mathrm{MJ} / \mathrm{m}^{2}\right)$ & 24.07 & 16.60 & 22.57 & 0.40 \\
Peak heat release rate, $\left(\mathrm{kW} / \mathrm{m}^{2}\right)$ & 210.50 & 188.55 & 350.11 & 1.72 \\
Total oxygen consumed $(\mathrm{g})$ & 15.40 & 10.53 & 14.80 & 0.17 \\
Density $\left(\mathrm{kg} / \mathrm{m}^{3}\right)$ & 24.9 & 17.7 & 1904.6 & 7708.2 \\
Mass loss $\left(\mathrm{g} / \mathrm{m}^{2}\right)$ & 12.40 & 8.13 & 1074.63 & 66.40 \\
Total smoke production $\left(\mathrm{m}^{2}\right)$ & 6.07 & 7.80 & 7.17 & 0.20 \\
\hline
\end{tabular}

(a)

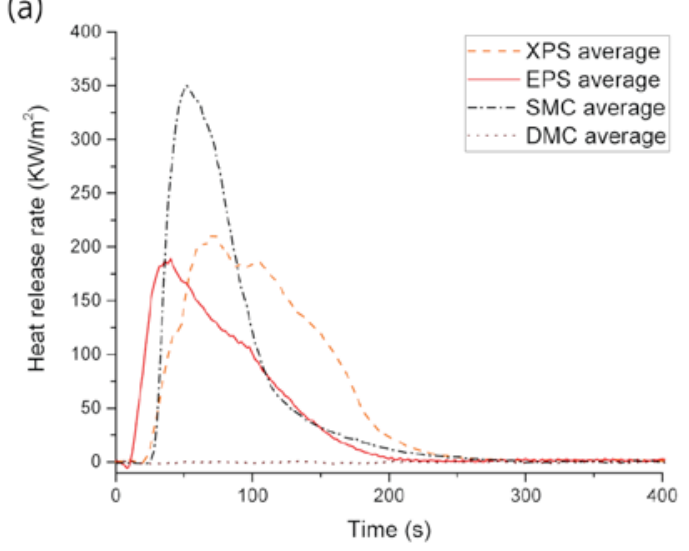

(b)

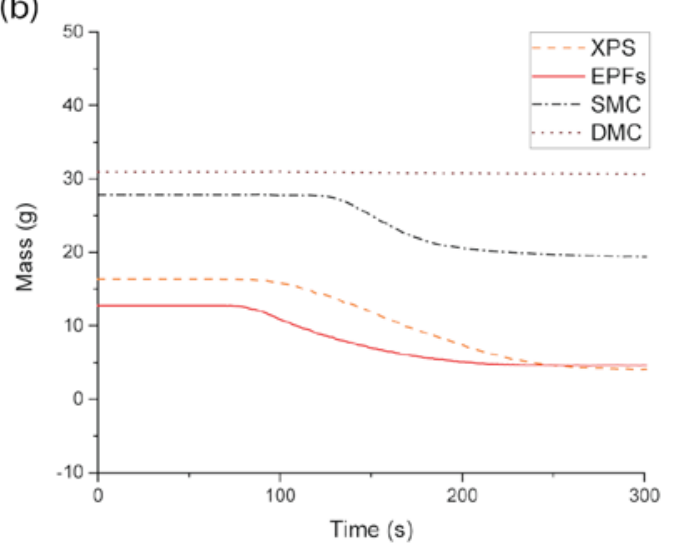

Figure 5. Results of the cone calorimetry test of each specimen: (a) Heat release rate variation and (b) mass variation.

\subsection{Preliminary Ignition Test}

The flame behavior of the preliminary ignition test is shown in Figure 6. The fire spread from the ignited XPS. At $20 \mathrm{~s}$ after the start of the test, the molten XPS dropped to the SMC, forming a new ignition source. The gradually deposited molten XPS generated flashover at $100 \mathrm{~s}$ after the start of the test and the firepower increased rapidly. This phenomenon suggests that when XPS is used as the thermal insulation material, the molten XPS can cause the spread of the ignition source. 

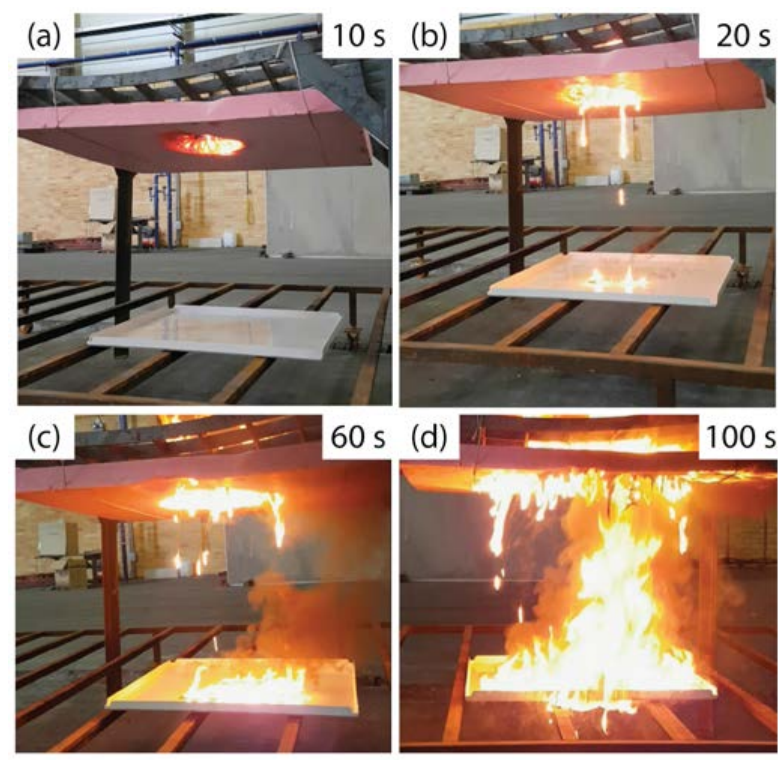

Figure 6. Fire behavior in the preliminary ignition test (XPS + SMC).

\subsection{Small-Scale Model Fire Test}

Figure 7 depicts changes in heat detector temperature over time for different combinations of thermal insulation and ceiling materials. Fire behavior over time for each material in the small-scale model test is depicted in Figure 8 and thermal images over time for each material in the small-scale model test are depicted in Figure 9.
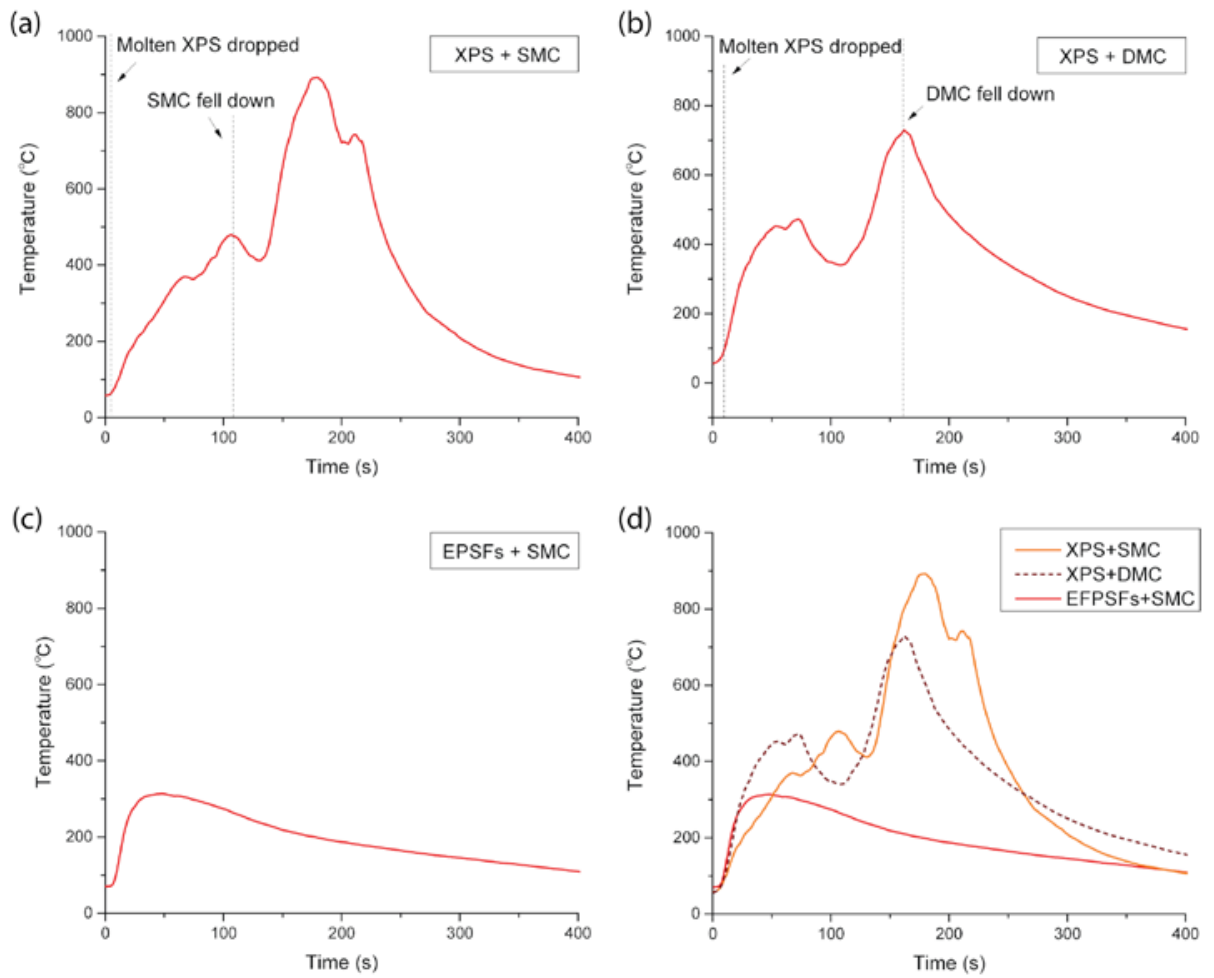

Figure 7. Changes in heat detector temperature over time for different combinations of thermal insulation and ceiling materials: (a) XPS + SMC, (b) XPS + DMC, (c) EPSFs + SMC, and (d) variation in temperature change by structures installed with different materials. 


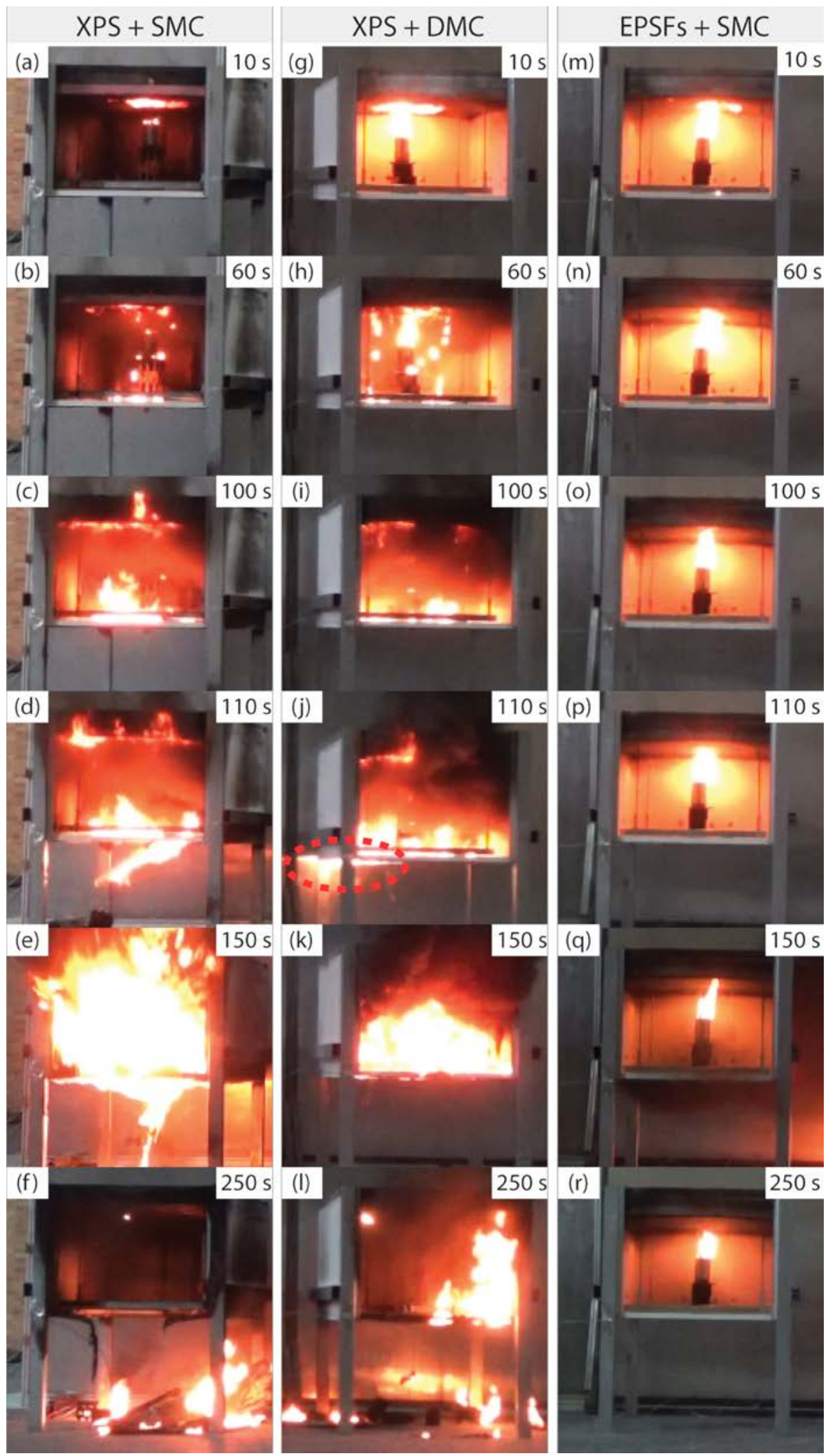

Figure 8. Fire behavior over time for each material in the small-scale model test. (a-f): XPS + SMC, $(\mathbf{g}-\mathbf{l}):$ XPS + DMC, $(\mathbf{m}-\mathbf{r}):$ EPSFs + SMC. 


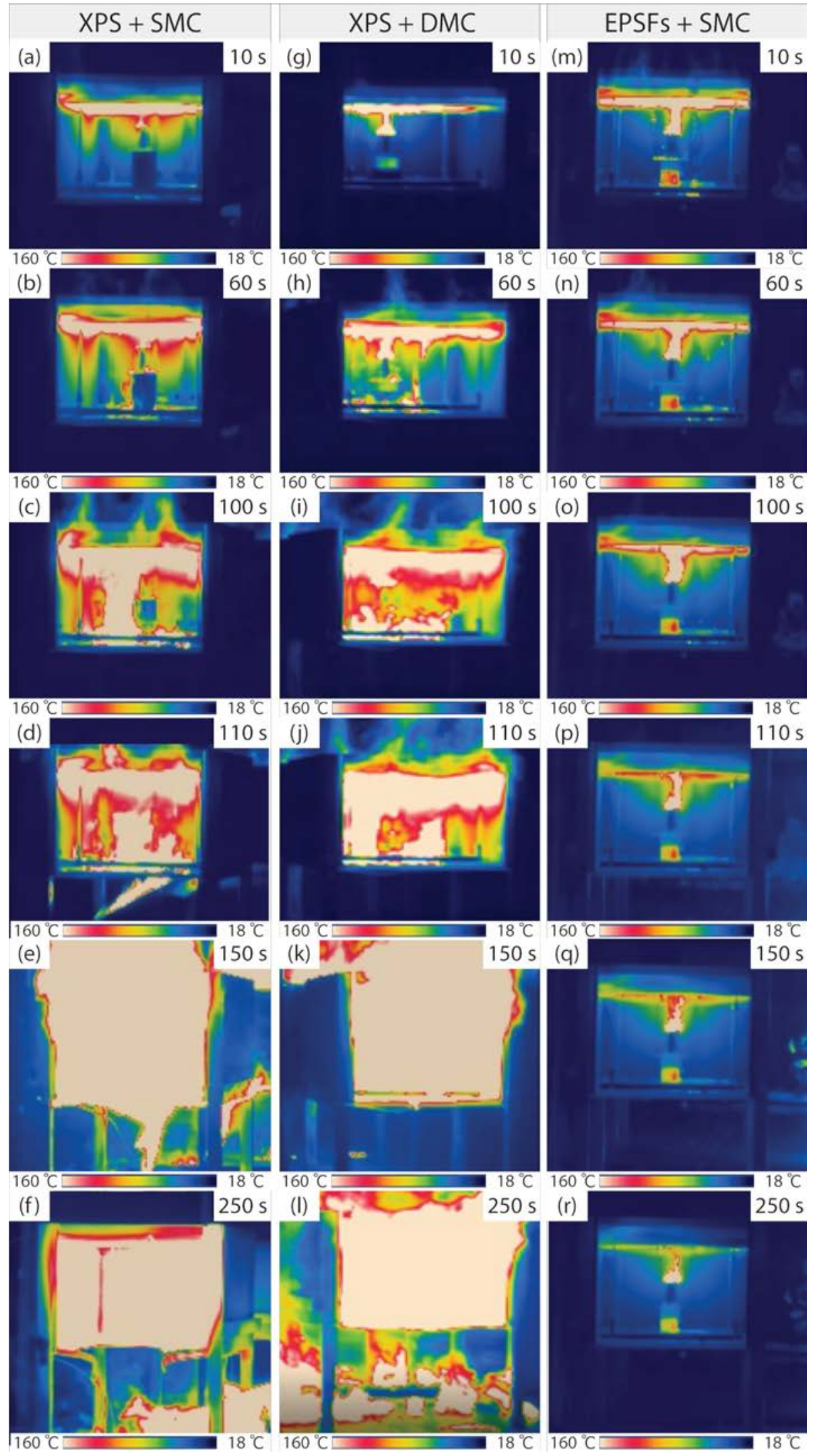

Figure 9. Thermal images over time for each material in the small-scale model test. (a-f): XPS + SMC, $(\mathbf{g}-\mathbf{l}):$ XPS + DMC, $(\mathbf{m}-\mathbf{r})$ EPSFs + SMC. 


\subsubsection{XPS + SMC}

At $15 \mathrm{~s}$ after the start of the test, molten XPS dropped on the SMC. As the fire on the molten XPS that dropped on the SMC spreads, the ignition source enlarged, and the fire intensity increased rapidly. At $110 \mathrm{~s}$ after the start of the test, the SMC ceiling materials peeled off from the ceiling structure support due to the increased fire intensity and dropped on the floor due to gravity (Figure 8j). After that, the rapid oxygen inflow caused a flashover.

The changes in the temperatures measured by the heat detector (Figure 7a) also show that the temperature inside the model increased sharply with the deposition of molten XPS. After the SMC peeled off at $110 \mathrm{~s}$, the temperature decreased temporarily as the ignition source moved away from the heat detector. However, the temperature increased again as the fire increased rapidly due to the inflow of outside oxygen. After $200 \mathrm{~s}$, when the SMC collapsed completely, the temperature gradually decreased as the flame did not touch the heat detector.

\subsection{2. $\mathrm{XPS}+\mathrm{DMC}$}

Similar to XPS + SMC, the molten XPS dropped to the DMC ceiling materials $15 \mathrm{~s}$ after the start of the ignition. As shown in Figure 8, as the molten XPS deposited on the DMC, a combustible gas was generated, and the fire intensity increased rapidly. Furthermore, the soot emanating from the XPS thermal insulation materials filled the inside of the small-scale model, and the fire intensity decreased sharply due to lack of oxygen. This can be confirmed in the thermogram in Figure 9. At $110 \mathrm{~s}$ after the test, the light of a flame was observed (Figure 8j), which means that the DMC was deformed. Air (oxygen) was supplied through the deformed joint of the DMC, thus increasing the fire intensity. At $160 \mathrm{~s}$ after the start of the test, a flashover occurred inside the DMC, and the DMC collapsed rapidly as if it exploded, rather than slowly, and the heat detector installed at the top was removed from the specimen and could not measure the temperature. Furthermore, unlike the XPS + SMC specimen, although the deposited ignition source of XPS was spread to most of the ceiling material area, the DMC ceiling materials of the XPS + DMC specimen did not collapse for $\sim 50 \mathrm{~s}$, even after the SMC ceiling materials collapsed.

\subsubsection{EPSFs + SMC}

When EPSF was used as the thermal insulation material, it did not drop even when the molten XPS, the ignition source, was deposited continuously, because the EPSF was treated with a flame-retardant during the manufacturing process and only the beads that touched the ignition source were burned and dropped as small carbonized granules onto the ceiling materials [2,31,32]. Thus, this material did not form an ignition source strong enough to spread the fire. As shown by the thermographic measurement result (Figure 9), no additional ignition source was formed above the ceiling materials, and the ignition source weakened due to insufficient oxygen.

As shown in Figure 7c, in this small-scale test, the temperature of the part above the specimen did not exceed $320^{\circ} \mathrm{C}$, and the SMC ceiling materials were not removed by heating. Thus, fire did not spread by the inflow of large volumes of oxygen.

\subsection{Real-Scale Fire Test}

\subsubsection{XPS + SMC}

Fire behavior in real-scale fire tests and thermographic measurement of XPS + SMC are shown in Figure 10 and the temperature changes for the top and bottom heat detectors in real-scale fire tests of XPS + SMC are shown in Figure 11. 


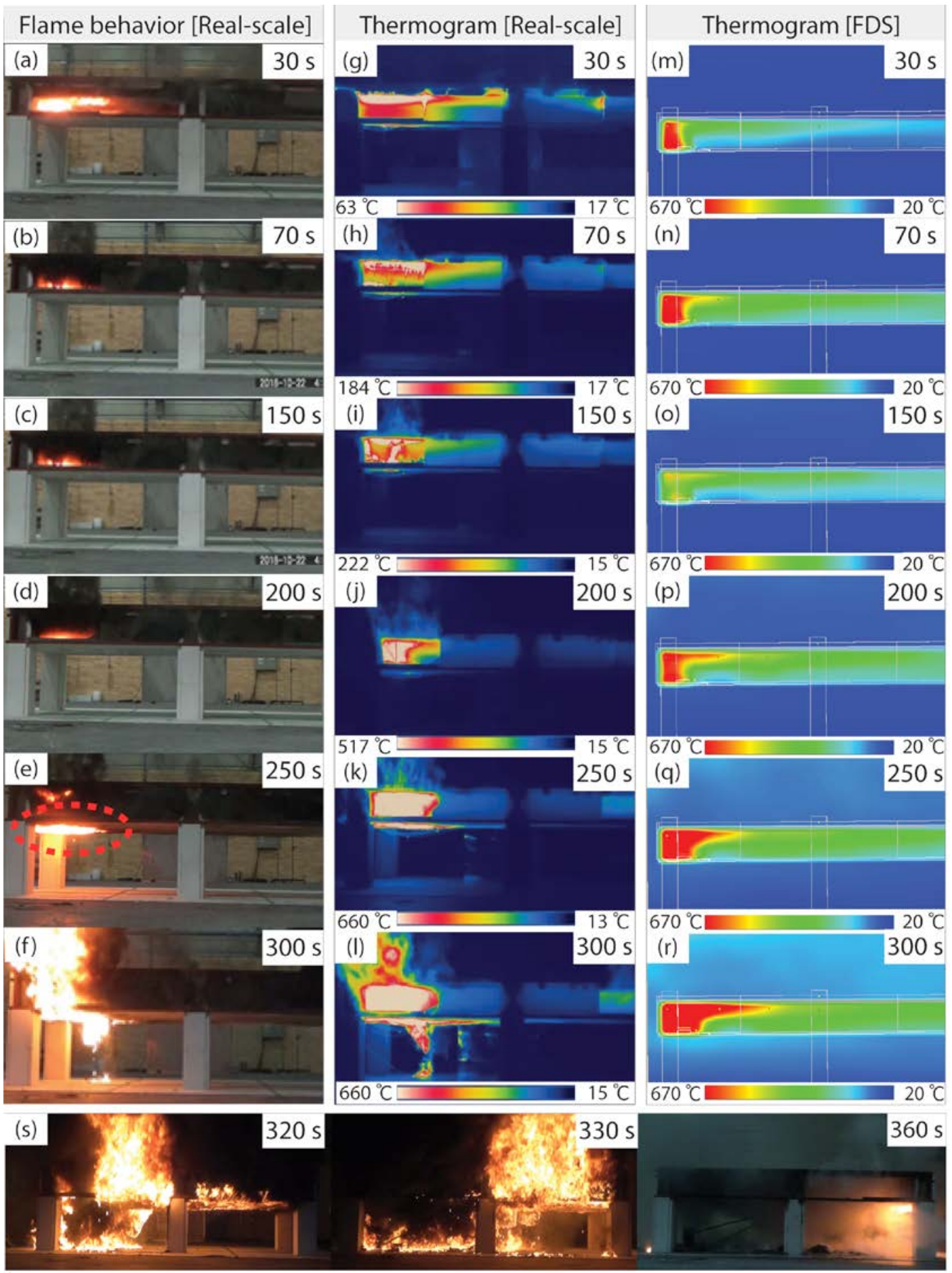

Figure 10. (a-f) Flame behavior of real-scale specimens in XPS + SMC real-scale fire tests and thermographic measurements, $(\mathbf{g}-\mathbf{l})$ thermogram of real-scale fire test specimens in XPS + SMC, $(\mathbf{m}-\mathbf{r})$ thermogram of FDS specimens in XPS + SMC, and (s) flame behavior after flashover. 

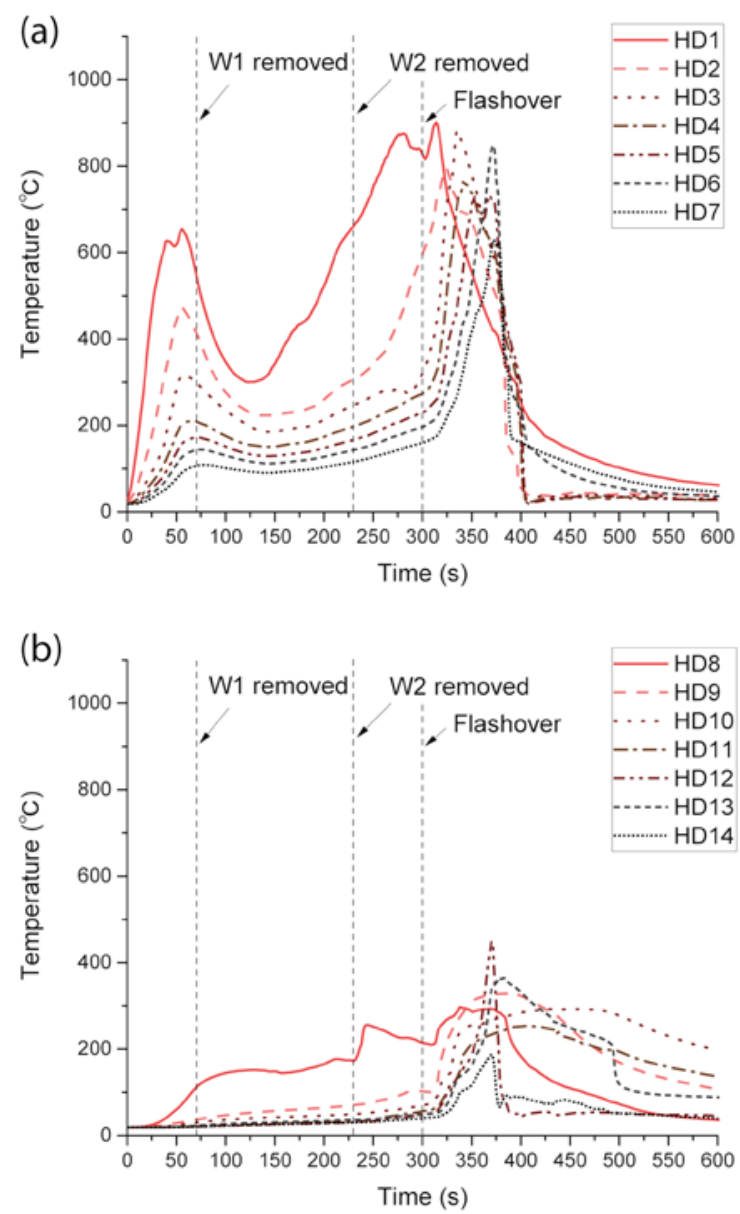

Figure 11. Temperature changes for the (a) top and (b) bottom heat detectors in XPS + SMC real-scale fire tests.

The temperature of the ignition source increased steadily until $50 \mathrm{~s}$ after ignition, and then the flame weakened due to insufficient oxygen. This result is different from the result of the small-scale model test where the fire intensity did not decrease significantly because the space was not sealed completely, causing penetration of outer air, and the ignition source size was smaller than that in the real-scale model test. After the fire intensity decreased, the left (W1) polycarbonate wall of the specimen was removed for oxygen supply at $70 \mathrm{~s}$ after ignition. As a result, the fire intensity increased again. After that, the fire became more intense as the ignition source was enlarged by the molten XPS that dropped on the SMC ceiling materials and reacted with oxygen.

After $250 \mathrm{~s}$, part of the SMC ceiling materials dropped to the first floor, the combustible gas escaped to the bottom of the specimen, and the outside air rapidly flowed into it. Consequently, the fire size increased sharply, and the same flashover phenomenon occurred as in the small-scale model test.

The low temperature measured by the heat detector despite removing the $\mathrm{W} 1$ plane at $~ 70 \mathrm{~s}$ can be analyzed as follows. The volume of ambient oxygen decreased due to the combustible gases and smoke accumulated inside the specimen, and the fire intensity decreased temporarily due to insufficient oxygen, or the flame moved toward the opposite direction of the W1 plane and away from the heat detector due to the oxygen inflow. The cause of the temperature reduction between $50 \mathrm{~s}$ and $120 \mathrm{~s}$ was also discussed based on the FDS results. Furthermore, since the melting of the XPS thermal insulation materials in the small-scale model test started within $10 \mathrm{~s}$ after heating, we can propose that the molten XPS thermal insulation materials accumulated on the SMC ceiling materials in the main test as well. After $120 \mathrm{~s}$, the molten XPS thermal insulation materials accumulated sufficiently on the SMC ceiling materials and contacted with the outside oxygen that came in through the defects 
in the SMC ceiling materials. Therefore, the fire intensity increased sharply. As can be seen from the $250 \mathrm{~s}$ image of the real-scale fire test in Figure 10e, when the flame is attached to the bottom of the ceiling materials, combustible materials leaked out through the defects of the SMC, and fire spread using these combustible materials as mediators. After that, the fire spread to the entire inside space of the ceiling, the heat detector dropped to the first floor, and the first-floor bottom part of the ceiling materials collapsed simultaneously. Consequently, the heat detector could not measure the temperatures properly.

\subsection{2. $\mathrm{EPSF}+\mathrm{DMC}$}

The test with the EPSFs and DMC was conducted for $600 \mathrm{~s}$, but the EPSFs did not melt and no flame-induced deformation occurred during the test. Thus, the DMC also did not deform and did not drop down to the floor. An additional experiment was performed by adding the same ignition sources to the middle and right side of the specimen under the same test conditions, and the results were identical. This shows that the gases generated by the combustion of the internal combustibles cannot be considered a cause of fire spread. On the contrary, fire did not spread from the EPSFs, and the combustibles burned by the ignition source formed bead-shaped carbonized membranes and dropped [2,31,32]. Thus, they did not affect the DMC ceiling materials and the DMC did not deform or drop to the ground.

The temperatures measured by the heat detectors in Figure 12 show that the temperature at HD1, which is the closest to the ignition source, increased to $800{ }^{\circ} \mathrm{C}$ and then gradually decreased with decreasing fire strength due to the reduction of oxygen. As shown in Figure 12, after removal of the W1 plate, the temperature did not decrease, as observed in the XPS + SMC test. The reason of the stable temperature was further investigated by FDS.

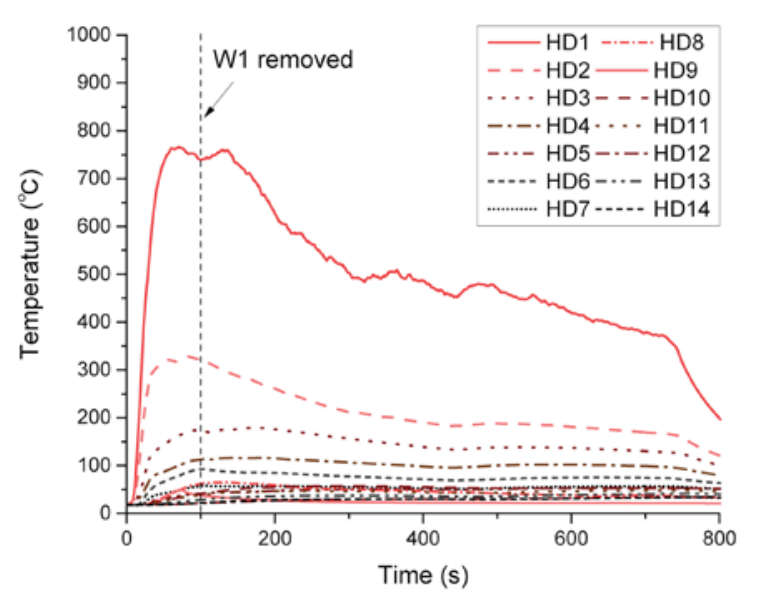

Figure 12. Changes in temperature for top and bottom heat detectors in the EPSFs + DMC real-scale fire test.

\subsection{Analysis of Fire Dynamic Simulation (FDS)}

As can be seen from the flame behavior observed through the real-scale fire test results and thermogram result of the FDS (Figure 13), the overall real-scale fire patterns were approximately similar in the fire test and the simulation. However, the detailed shape of thermogram of FDS and real-scale fire test are different because it is difficult to accurately match the fluctuation of ambient oxygen inflow to the change in the size and intensity of the ignition source. Furthermore, since the thermogram of real-scale fire test was detected from the right side of the structure, there were remarkable differences in the detected temperature due to irregular depth and presence or absence of W1. 

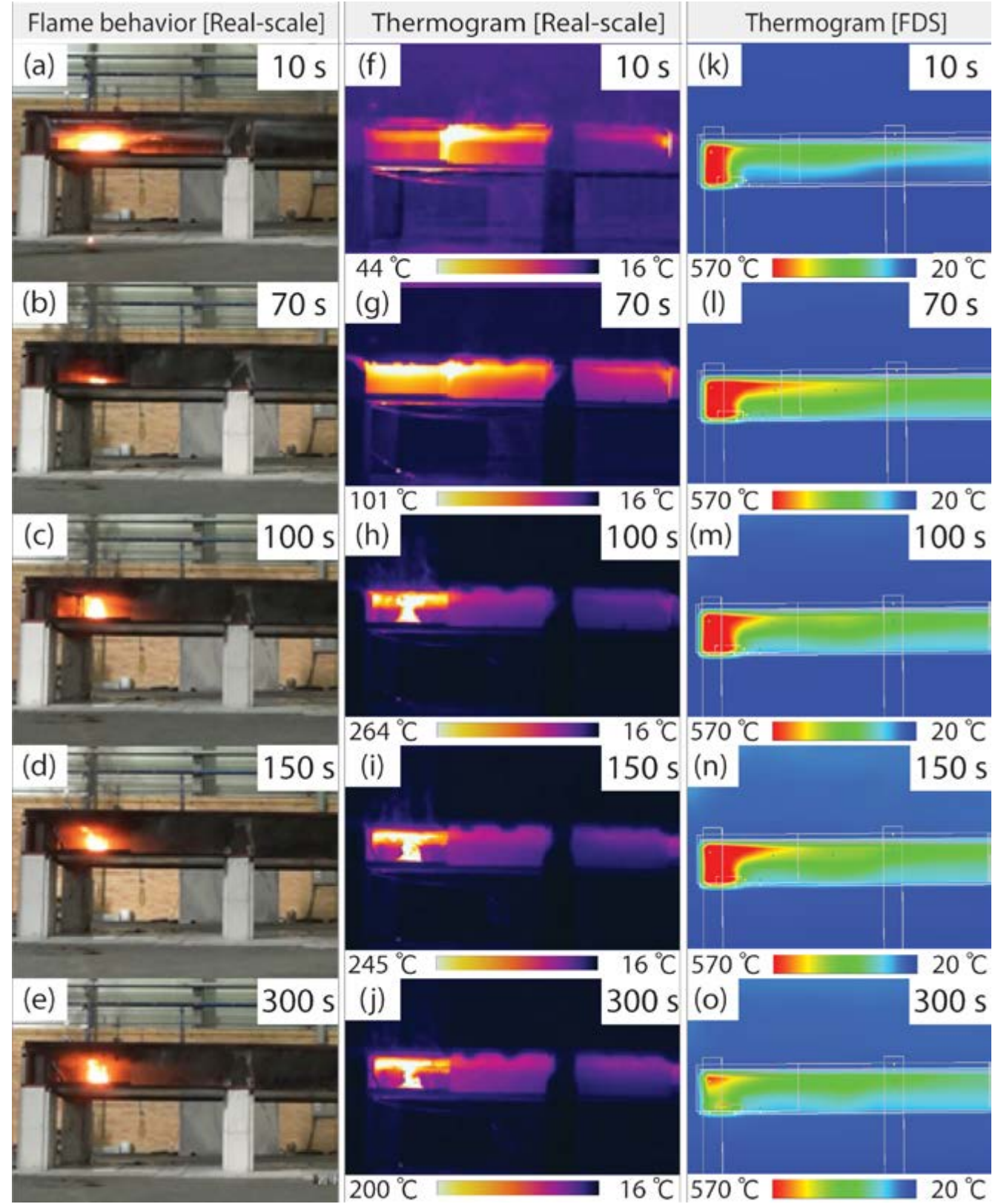

Figure 13. (a-e) Flame behavior of real-scale specimens in EPSFs + DMC real-scale fire tests and thermographic measurements, $(\mathbf{f}-\mathbf{j})$ thermogram of real-scale fire test specimens in EPSFs + DMC, $(\mathbf{k}-\mathbf{o})$ thermogram of FDS specimens in EPSFs + DMC.

Figures 14 and 15 depict that the changes in temperature after additional changes to fit the result of FDS to those of the real-scale tests using XPS + SMC and EPSFs + DMC, respectively. In the FDS, the phenomenon of increasing ignition sources by molten XPS cannot be reproduced. Thus, the temperature detected at HD1 in FDS remains stable even after removing W1, as shown in Figure 16a. Therefore, the FDS results appeared similar to the changes in temperature of the real-scale fire model test only when an additional ignition source was set at the location where the molten XPS was deposited and an additional setting was applied to increase the strength of fire over time. 
(a)

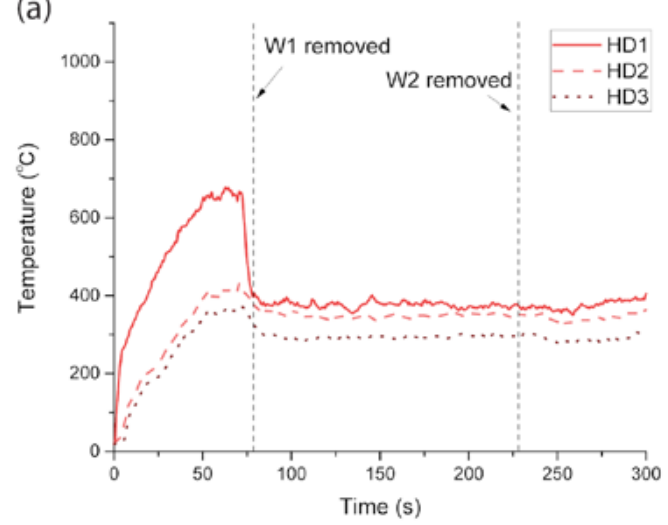

(c)

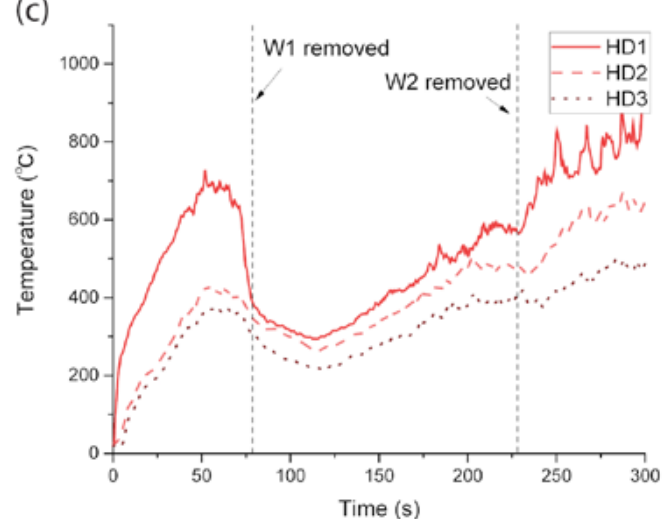

(d)

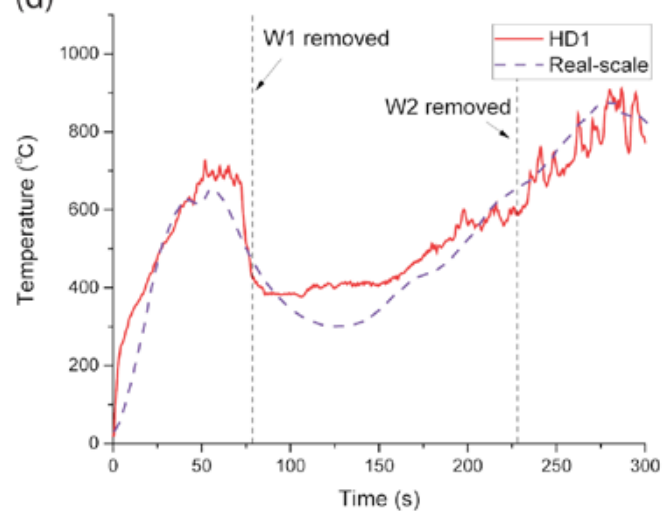

(b)
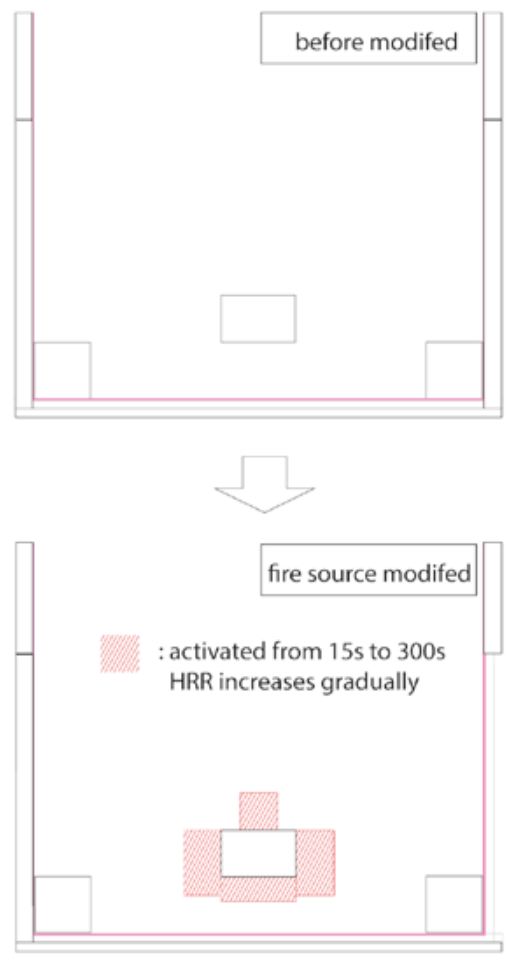

(e)

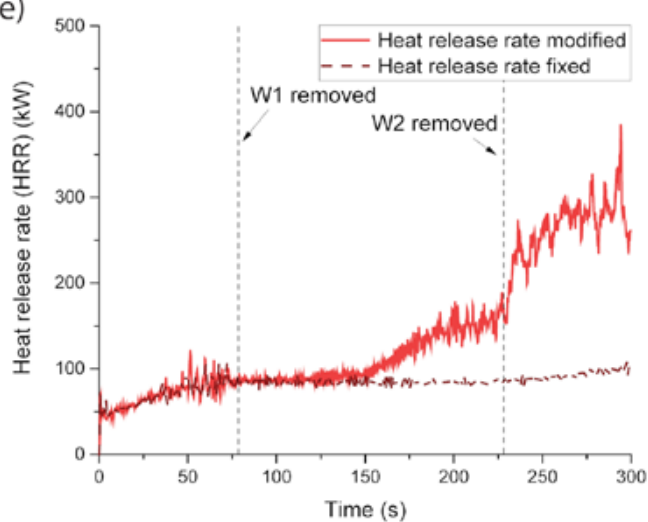

Figure 14. Comparison between the temperature measurement results of real-scale fire tests and FDS specimens in XPS + SMC. (a) Temperature changes detected at HD1 when the intensity and size of the ignition source are fixed, (b) ignition source expansion due to molten XPS, (c) temperature changes detected at HD1 considering the increase of ignition sources and molten XPS, (d) relationship between real-scale fire test and FDS, and (e) changes in heat release rate before and after modification of fire source. 
(a)

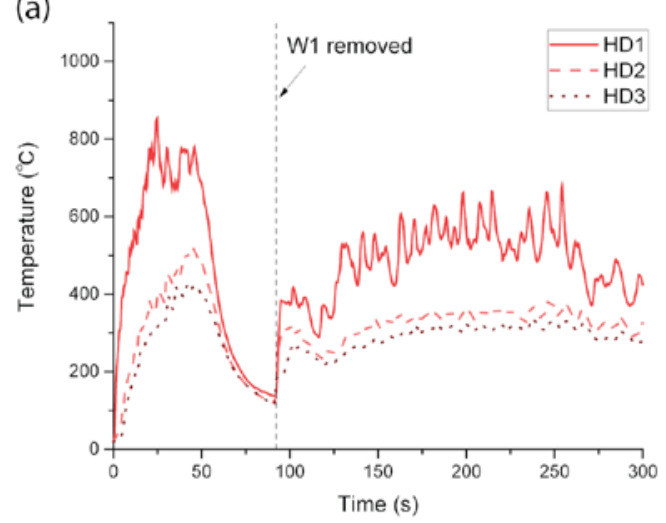

(c)

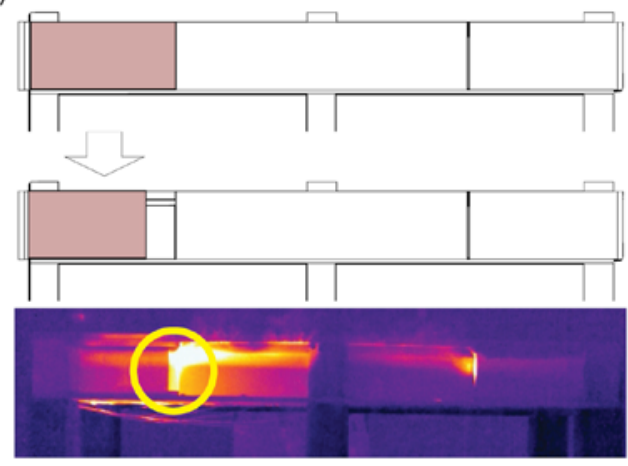

(b)

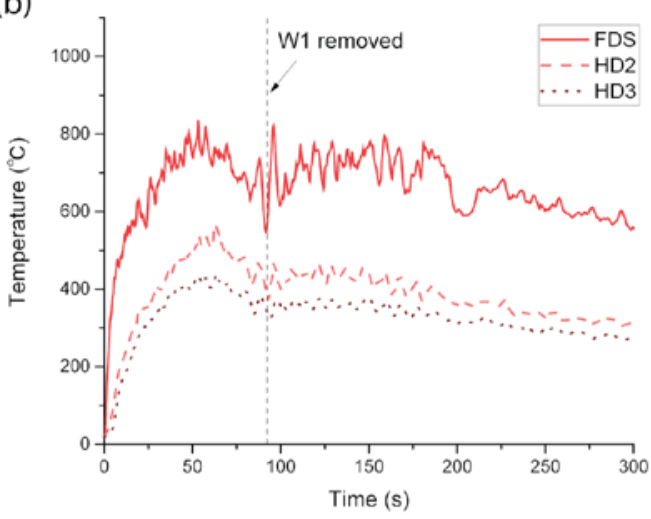

(d)

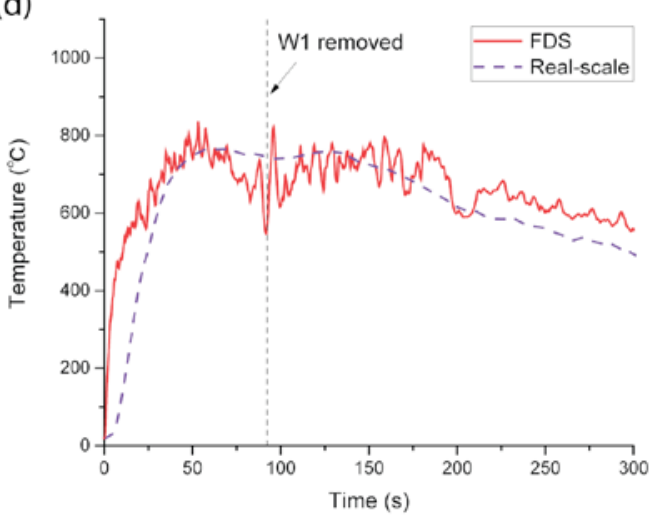

Figure 15. Comparison between the temperature measurement results in HD1 between the real-fire test and FDS specimens in EPSFs + DMC: (a) W1 is completely sealed and (b) W1 is open at $0.3 \mathrm{~m}$. (c) Differences in elevation before and after opening of W1 and (d) comparison of the temperature measurement results in HD1 between the real-fire test and the W1 modified FDS.

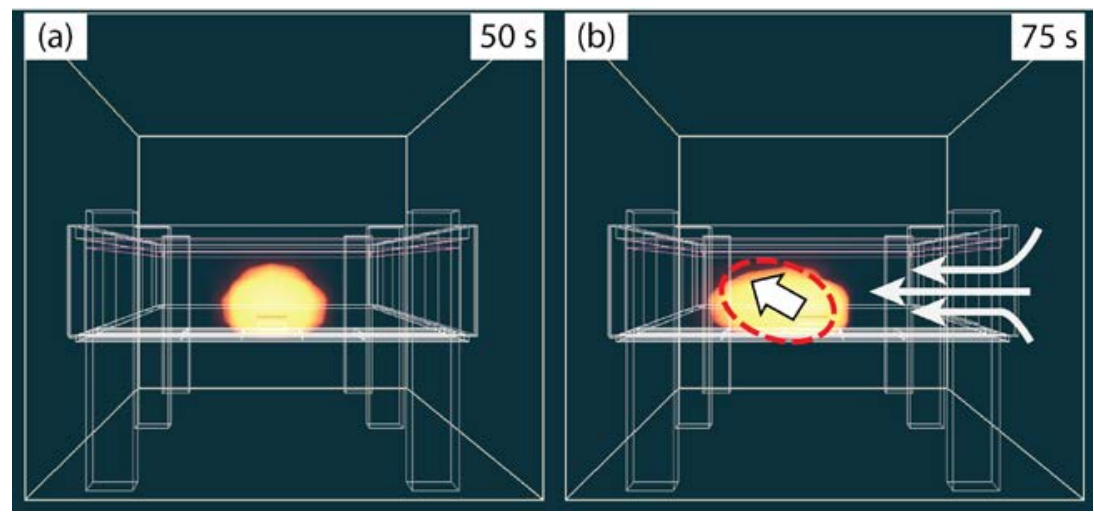

Figure 16. Changes in the flame direction before and after the opening of W1.

However, the reason for the decrease in temperature from $50 \mathrm{~s}$ to $120 \mathrm{~s}$ in the XPS + SMC test could not be identified in the real-scale fire test but could be identified using the FDS. As can be seen in Figure 16, the FDS result suggests that as the outside air rapidly entered the model due to an air pressure difference between the inside and outside of the model when the W1 plane was removed, the direction of the flame turned toward a direction opposite to the W1 plane, and the temperature of flame was not detected directly by HD1.

In contrast, the temperature did not decrease significantly in the EPSFs + DMC test, even when W1 was removed. This phenomenon suggests that the direction of the ignition source was not substantially 
turned because the air pressure difference between the inside and outside of the model before the removal of W1 was not large and the penetration of outside air through W1 was relatively weak. There are two reasons for the small difference between the outside and inside air pressures of the specimen. First, in the XPS + SMC test, the molten XPS began to be deposited from $10 \mathrm{~s}$ after the start of the test, and the ignition source continuously increased in size. Thus, oxygen consumption through this ignition source was more active. Thus, a larger difference in air pressure was observed when W1 was removed. Second, as shown in Figure 15c, the W1 plane of the specimen in the EPSFs + DMC test was partly open from the beginning, and the outside air inflow by the air pressure difference was weaker than that in the XPS + SMC test. Moreover, when the EPSFs + DMC specimen was less sealed than the XPS + SMC specimen, the FDS results were closer to those obtained in the real-scale model experiment (Figure 15d).

A comparison of the results between the real-scale fire test and the FDS of piloti-type structure showed that the type of thermal insulation material, the type of ceiling material, and the properties of the combustible materials influenced the combustibility and fire spread inside the ceiling. When XPS was used as the thermal insulation material, the molten XPS generated additional ignition sources above the ceiling materials and spread and sustained the combustion. Furthermore, as the combustible gases leaked to the bottom through the gaps produced by deformation of the ceiling materials, they removed these materials causing fire spread. Outside air flows in through the removed part, causing a flashover, during which the fire intensity and the degree of fire spread increase enormously.

These results show the limitations and advantages of the real-scale fire test and the FDS. One limitation of the FDS is that it cannot simulate the phenomenon involving the melting of a solid $[27,28]$. Thus, the XPS + SMC real-scale fire test could not reproduce the phenomenon in which the molten XPS increases the ignition sources. In other words, FDS cannot specifically simulate the situation of fire spread by molten XPS dropping from the inside surface of the SMC ceiling materials, instead of the ignition source that was originally installed. The temperature changes simulated in the FDS similar to those recorded by heat detectors in the real-scale fire test could only be obtained when artificial settings were added, such as intentionally setting an air inflow by eliminating some of the SMC ceiling materials or by increasing the intensity of the original ignition source at the appropriate moment during the real-scale fire test. Furthermore, the real-scale fire test has a limitation in that it cannot be performed multiple times owing to the large scale and cost of the test. Thus, it was difficult to analyze the cause of the phenomenon in which the temperature did not decrease even when W1 was removed during the EPSFs + DMC test. However, the FDS could support this limitation because, while obtaining results similar to those of the real-scale fire test, it was possible to determine which parameter had a large effect on the temperature change by revising the probable parameters.

\section{Conclusions}

In this study, flame behavior, temperature change over time, and causes of spread to large-scale fires were analyzed using a small-scale fire test and a real-scale fire test simulating the structure of the piloti-type buildings. Furthermore, the flame behavior and variations in temperature were analyzed using the FDS, whose parameters were obtained by cone calorimetry tests, and were compared with those of the real-scale fire tests.

1. A preliminary test was conducted using the XPS + SMC structure simulating the worst fire situation before the small-scale test. In this test, the fire started when the thermal insulation materials were exposed to an ignition source. As the molten XPS dropped onto the SMC ceiling materials, new ignition sources were formed, which led to fire spread by the surrounding combustible gases and oxygen. The deposition of molten XPS onto the ceiling materials when it was exposed to fire, increased the ignition sources. This phenomenon occurred in both the small-scale and real-scale fire tests where XPS was used as the thermal insulation material.

2. When the structure in which the XPS was used as the thermal insulation material was exposed to an ignition source in the small-scale test, the molten XPS accumulated from $15 \mathrm{~s}$ after the test start, 
and the ignition sources increased, thus increasing the fire intensity. After that, the fire intensity increased further as the ceiling materials (SMC, DMC) were deformed and outside air flowed in. As a result, the ceiling materials collapsed. However, when EPSFs were used as thermal insulation materials, the fire temperature increased to $300^{\circ} \mathrm{C}$, and then the fire was weakened and extinguished due to lack of oxygen.

3. In the real-scale fire test, the XPS + SMC structure showed a rise in temperature as the ignition sources increased due to the deposition of molten XPS. After the SMC was deformed, the combustible gases moved to the ceiling materials and caused fire spread. As a result, the ceiling materials collapsed and large volumes of outside air (oxygen) flowed in, resulting in a flashover phenomenon, in which the fire intensity and the degree of fire spread increased rapidly. However, in the EPSFs + DMC structure, the phenomenon of increasing ignition sources due to the deposition of melts did not occur. Therefore, the deformation of DMC did not occur, and the temperature decreased as the oxygen and fuel inside the specimen decreased.

4. When the FDS analysis was performed only with the data obtained using cone calorimetry and the information of the ignition source, it showed many differences with the results of the real-scale fire test. Change in temperature detected by the heat detector similar to that of the real-scale fire test could be obtained only when the expansion of ignition sources due to the deposition of molten XPS was artificially set and the phenomenon in which the fire strength was increased by outside air inflow due to deformation of the ceiling materials was additionally set.

5. The limitation of the FDS tool is that it is difficult to accurately reproduce fire situations using it, even though it is the most widely used analysis tool for numerical simulations. It was found that a real-scale fire test is essential, not only for fires in ceilings but also for other fire situations, and additional parameters of the actual fire are needed to improve the accuracy of the FDS. Furthermore, to avoid fire damage in ceilings, which is the subject of this study, further research is necessary on the sprinkler type (vaporization type) in the ceiling and on the melting characteristics and properties of the thermal insulation materials.

Author Contributions: Investigation, H.-W.S., S.-M.L. and T.-H.P.; resources, H.-W.S. and H.-J.K.; visualization, H.-W.S., S.-M.L. and T.-H.P.; writing-original draft, H.-W.S., H.-J.K. and S.-C.B.; writing-review and editing, H.-S.K., H.-K.C., J.-H.C. and S.-C.B.

Funding: This research was funded by the National Fire Agency, "NEMA-Next Generation-2014-58".

Acknowledgments: This research was supported by the Field-oriented Support of Fire Fighting Technology Research and Development Program funded by National Fire Agency ("NEMA-Next Generation-2014-58").

Conflicts of Interest: The authors declare no conflict of interest.

\section{References}

1. Zhou, Y.; Bu, R.W.; Gong, J.H.; Yan, W.G.; Fan, C.G. Experimental investigation on downward flame spread over rigid polyurethane and extruded polystyrene foams. Exp. Therm. Fluid Sci. 2018, 92, 346-352. [CrossRef]

2. An, W.G.; Sun, J.H.; Liew, K.M.; Zhu, G.Q. Effects of building concave structure on flame spread over extruded polystyrene thermal insulation material. Appl. Eng. 2017, 121, 802-809. [CrossRef]

3. Xu, Q.; Jin, C.; Jiang, Y. Compare the flammability of two extruded polystyrene foams with micro-scale combustion calorimeter and cone calorimeter tests. J. Therm. Anal. Calorim. 2017, 127, 2359-2366. [CrossRef]

4. An, W.G.; Yin, X.W.; Chen, S.; Zhang, G.W. Study on downward flame spread over extruded polystyrene foam in a vertical channel: Influence of opening area. Fire Mater. 2019, 43. [CrossRef]

5. Choi, S.B.C. Don Mook A Study on Fire Risk of Apartment House with Pilotis Structure - Focused on the Fire case of Uijeongbu-si Urban Livig Homes. Korean Inst. Fire Sci. Eng. 2016, 30, 48-54. [CrossRef]

6. Park, J.S. A Study on the Survey in Terms of Fire Safety of Urbanistic Housing. J. Korean Soc. Hazard Mitig. 2016, 16, 143-148. [CrossRef]

7. Lee, J.I.; Ha, K.C. A Study for the Fire Analysis and Igniting Cause of Freezing Protection Heating Cables. J. Korean Soc. Saf. 2018, 33, 15-20. 
8. Park, J.G. An Experimental Study on Heat Accumulation Limit of Heating Lamp andIdentification Error of a Source of Ignition. J. Fire Investig. Soc. Korea 2018, 9, 81-97.

9. Kim, H.J.; Park, J.Y.; Suh, H.W.; Cho, B.Y.; Park, W.J.; Bae, S.C. Mechanical Degradation and Thermal Decomposition of Ethylene-Vinyl Acetate (EVA) Polymer-Modified Cement Mortar (PCM) Exposed to High-Temperature. Sustainability 2019, 11, 500. [CrossRef]

10. Guillaume, E.; Didieux, F.; Thiry, A.; Bellivier, A. Real-scale fire tests of one bedroom apartments with regard to tenability assessment. Fire Saf. J. 2014, 70, 81-97. [CrossRef]

11. Fei, Y.; Zhou, J.J.; Zou, Y.H.; Li, P.D.; Lin, J.Z.; Chow, T.T. Preliminary real-scale experimental studies on cable fires in plenum. J. Fire Sci. 2003, 21, 465-484. [CrossRef]

12. Capote, J.A.; Alvear, D.; Lazaro, M.; Espina, P. Heat release rate and computer fire modelling vs real-scale fire tests in passenger trains. Fire Mater. 2008, 32, 213-229. [CrossRef]

13. Zhang, C.; Choe, L.; Gross, J.; Ramesh, S.; Bundy, M. Engineering Approach for Designing a Thermal Test of Real-Scale Steel Beam Exposed to Localized Fire. Fire Technol. 2017, 53, 1535-1554. [CrossRef]

14. Melcher, T.; Zinke, R.; Trott, M.; Krause, U. Experimental investigations on the repeatability of real scale fire tests. Fire Saf. J. 2016, 82, 101-114. [CrossRef]

15. Srivastava, G.; Ghoroi, C.; Gandhi, P.; Jagdish, V.; Karthikeyan, G.; Chakravarthy, A.; Nakrani, D. Development of a unique full-scale real-fire facade testing facility at IIT Gandhinagar. Curr. Sci. India 2018, 115, 1782-1787. [CrossRef]

16. Tao, H.W.; Zhang, X.C.; Guo, Z.M.; Zeng, W.Y.; Huang, X.J.; Zheng, Z.H.; Xu, W.B. Combustion characteristics and heat release rate of vertical cable fire for sustainable energy system in an analogue underground compartment. Sustain. Cities Soc. 2019, 45, 406-412. [CrossRef]

17. Xu, Q.F.; Wang, Y.; Chen, L.Z.; Gao, R.D.; Li, X.M. Comparative experimental study of fire-resistance ratings of timber assemblies with different fire protection measures. Adv. Struct. Eng. 2016, 19, 500-512. [CrossRef]

18. Lacanette, D.; Mindeguia, J.C.; Brodard, A.; Ferrier, C.; Guibert, P.; Leblanc, J.C.; Malaurent, P.; Sirieix, C. Simulation of an experimental fire in an underground limestone quarry for the study of Paleolithic fires. Int. J. Therm. Sci. 2017, 120, 1-18. [CrossRef]

19. Drean, V.; Schillinger, R.; Leborgne, H.; Auguin, G.; Guillaume, E. Numerical Simulation of Fire Exposed Fa double dagger ades Using LEPIR II Testing Facility. Fire Technol. 2018, 54, 943-966. [CrossRef]

20. Sellami, I.; Manescau, B.; Chetehouna, K.; de Izarra, C.; Nait-Said, R.; Zidani, F. BLEVE fireball modeling using Fire Dynamics Simulator (FDS) in an Algerian gas industry. J. Loss Prev. Process Ind. 2018, 54, 69-84. [CrossRef]

21. Yu, L.X.; Beji, T.; Maragkos, G.; Merci, B.; Liu, F.; Weng, M.C. Assessment of Numerical Simulation Capabilities of the Fire Dynamics Simulator (FDS 6) for Planar Air Curtain Flows. Fire Technol. 2018, 54, 583-612. [CrossRef]

22. Kolaitis, D.I.; Founti, M.A. Development of a solid reaction kinetics gypsum dehydration model appropriate for CFD simulation of gypsum plasterboard wall assemblies exposed to fire. Fire Saf. J. 2013, 58, 151-159. [CrossRef]

23. Qi, D.H.; Wang, L.Z.; Zmeureanu, R. An analytical model of heat and mass transfer through non-adiabatic high-rise shafts during fires. Int. J. Heat Mass Transf. 2014, 72, 585-594. [CrossRef]

24. Thanasoulas, I.D.; Vardakoulias, I.K.; Gantes, C.J.; Kolaitis, D.I.; Founti, M.A. Thermal and Mechanical Computational Study of Load-Bearing Cold-Formed Steel Drywall Systems Exposed to Fire. Fire Technol. 2016, 52, 2071-2092. [CrossRef]

25. Nilsson, M.; Husted, B.; Mossberg, A.; Anderson, J.; McNamee, R.J. A numerical comparison of protective measures against external fire spread. Fire Mater. 2018, 42, 493-507. [CrossRef]

26. Hopkin, C.; Spearpoint, M.; Bittern, A. Using experimental sprinkler actuation times to assess the performance of Fire Dynamics Simulator. J. Fire Sci. 2018, 36, 342-361. [CrossRef]

27. Aschaber, M.; Feist, C.; Hofstetter, G. Numerical simulation of the response of fire exposed concrete structure. Beton Stahlbetonbau 2007, 102, 578-587. [CrossRef]

28. Feist, C.; Aschaber, M.; Hofstetter, G. Numerical simulation of the load-carrying behavior of RC tunnel structures exposed to fire. Finite Elem. Anal. Des. 2009, 45, 958-965. [CrossRef]

29. Zhu, Z.M.; Xu, Y.J.; Liao, W.; Xu, S.M.; Wang, Y.Z. Highly Flame Retardant Expanded Polystyrene Foams from Phosphorus-Nitrogen-Silicon Synergistic Adhesives. Ind. Eng. Chem. Res. 2017, 56, 4649-4658. [CrossRef] 
30. Sayadi, A.A.; Tapia, J.V.; Neitzert, T.R.; Clifton, G.C. Effects of expanded polystyrene (EPS) particles on fire resistance, thermal conductivity and compressive strength of foamed concrete. Constr. Build. Mater. 2016, 112, 716-724. [CrossRef]

31. Zhang, Y.; Sun, J.H.; Huang, X.J.; Chen, X.F. Heat transfer mechanisms in horizontal flame spread over wood and extruded polystyrene surfaces. Int. J. Heat Mass Transf. 2013, 61, 28-34. [CrossRef]

32. An, W.G.; Xiao, H.H.; Liew, K.M.; Jiang, L.; Yan, W.G.; Zhou, Y.; Huang, X.J.; Sun, J.H.; Gao, L.J. Downward flame spread over extruded polystyrene. J. Therm. Anal. Calorim. 2015, 119, 1091-1103. [CrossRef]

33. Jiang, L.; Xiao, H.H.; Zhou, Y.; An, W.G.; Yan, W.G.; He, J.J.; Sun, J.H. Theoretical and experimental study of width effects on horizontal flame spread over extruded and expanded polystyrene foam surfaces. J. Fire Sci. 2014, 32, 193-209. [CrossRef]

34. Hapuarachchi, T.D.; Ren, G.; Fan, M.; Hogg, P.J.; Peijs, T. Fire retardancy of natural fibre reinforced sheet moulding compound. Appl. Compos. Mater. 2007, 14, 251-264. [CrossRef]

35. Pourali, A.; Dhakal, R.P.; MacRae, G.; Tasligedik, A.S. Fully Floating Suspended Ceiling System: Experimental Evaluation of Structural Feasibility and Challenges. Earthq. Spectra 2017, 33, 1627-1654. [CrossRef]

36. Long, X.F.; Zhang, X.Q.; Lou, B. Numerical simulation of dormitory building fire and personnel escape based on Pyrosim and Pathfinder. J. Chin. Inst. Eng. 2017, 40, 257-266. [CrossRef]

37. Tingyong, F.; Jun, X.; Jufen, Y.; Bangben, W. Study of Building Fire Evacuation Based on Continuous Model of FDS \& EVAC. In Proceedings of the 2011 International Conference on Computer Distributed Control and Intelligent Environmental Monitoring, Changsha, China, 19-20 February 2011; pp. 1331-1334.

38. Glasa, J.; Valasek, L.; Weisenpacher, P.; Halada, L. Cinema Fire Modelling by FDS. J. Phys. Conf. Ser. 2013, 410, 012013. [CrossRef]

39. Hongguo, X.; Na, L.; Hongfei, L.; Yihua, Z. Automotive Fire Simulation Based on Pyrosim. Green Intell. Transp. Syst. 2018, 419, 197-210.

(C) 2019 by the authors. Licensee MDPI, Basel, Switzerland. This article is an open access article distributed under the terms and conditions of the Creative Commons Attribution (CC BY) license (http://creativecommons.org/licenses/by/4.0/). 